\title{
Genetic interaction between DNA polymerase $\beta$ and DNA-PKcs in embryogenesis and neurogenesis
}

\author{
N Niimi ${ }^{1}$, N Sugo ${ }^{1,2}$, Y Aratani ${ }^{1}$ and H Koyama*, \\ ${ }^{1}$ Kihara Institute for Biological Research and Graduate School of Integrated \\ Science, Yokohama City University, 641-12 Maioka-cho, Totsuka-ku, \\ Yokohama 244-0813, Japan \\ 2 Current address: Graduate School of Frontier Biosciences, Osaka University, \\ 1-3 Yamadaoka, Suita, Osaka 565-0871, Japan \\ * Corresponding author: H Koyama, Kihara Institute for Biological Research, \\ Yokohama City University, 641-12 Maioka-cho, Totsuka-ku, Yokohama \\ 244-0813, Japan. Tel: +81-45-820-2440; Fax: + 81-45-820-1901; \\ E-mail: koyama@yokohama-cu.ac.jp
}

Received 20.7.04; revised 13.10.04; accepted 25.10.04 Edited by $Y$ Tsujimoto

\begin{abstract}
DNA polymerase $\beta(\mathrm{Pol} \beta)$ has been implicated in base excision repair. Pol $\beta$ knockout mice exhibit apoptosis in postmitotic neuronal cells and die at birth. Also, mice deficient in nonhomologous end-joining (NHEJ), a major pathway for DNA double-strand break repair, cause massive neuronal apoptosis. Severe combined immunodeficiency (SCID) mice have a mutation in the gene encoding DNA-dependent protein kinase catalytic subunit (DNA-PKcs), the component of NHEJ, and exhibit defective lymphogenesis. To study the interaction between Pol $\beta$ and DNA-PKcs, we generated mice doubly deficient in Pol $\beta$ and DNA-PKcs. Pol $\beta^{-l-}$ DNA-PKcs ${ }^{\text {scid/scid }}$ embryos displayed greater developmental delay, more extensive neuronal apoptosis, and earlier lethality than Pol $\beta^{-I}$ and DNAPKcs ${ }^{\text {scid/scid }}$ embryos. Furthermore, to study the involvement of $\mathrm{p} 53$ in the phenotype, we generated Pol $\beta^{-I-}$ DNAPKcs ${ }^{\text {scid/scid }} \mathrm{p53}^{-1-}$ triple-mutant mice. The mutants did not exhibit apoptosis but were lethal with defective neurulation at midgestation. These results suggest a genetic interaction between Pol $\beta$ and DNA-PKcs in embryogenesis and neurogenesis.
\end{abstract}

Cell Death and Differentiation (2005) 12, 184-191.

doi:10.1038/sj.cdd. 4401543

Keywords: apoptosis; DNA polymerase $\beta$; knockout mouse; neural development; SCID

Abbreviations: BER, base excision repair; CNS, central nervous system; DNA-PK, DNA-dependent protein kinase; DNA-PKcs, DNA-dependent protein kinase catalytic subunit; DSBs, double-strand breaks; E, embryonic day; NHEJ, nonhomologous end-joining; PNS, peripheral nervous system; Pol $\beta$, DNA polymerase $\beta$; PPL, primordial plexiform layer; SCID (DNA-PKcs ${ }^{\text {sid/scid}}$ ), severe combined immunodeficiency; SSBs, single-strand breaks; VZ, ventricular zone

\section{Introduction}

The genome is continuously damaged by a variety of endogenous and exogenous agents. Repair of such damage is a crucial mechanism for maintaining genomic integrity. A failure in faithful repair causes mutations with an increased risk of cancer. Multicellular animals have an additional mechanism for eliminating damaged cells called apoptosis. DNA polymerase $\beta(\mathrm{Pol} \beta)$ is a key factor in base excision repair (BER), ${ }^{1,2}$ which is the major pathway for the repair of small lesions such as apurinic/apyrimidinic (AP) sites and oxidized or alkylated bases. In fact, $\mathrm{Pol} \beta$-deficient cells are clearly more sensitive than wild-type cells to DNA alkylating agents ${ }^{3}$ and hydrogen peroxide. ${ }^{4} \mathrm{Pol} \beta$-null fibroblasts survive under culture conditions, ${ }^{3}$ suggesting that $\mathrm{Pol} \beta$ is not essential for all cell types. On the other hand, $\operatorname{Pol} \beta$ knockout mice die immediately after birth. ${ }^{5-7}$ We reported that the mutant mice exhibit extensive apoptosis in newly generated postmitotic neuronal cells in the central nervous system (CNS) and peripheral nervous system (PNS). In neurogenesis of the cerebral cortex, $^{8}$ neuronal progenitor cells initiate DNA replication and cell division in the ventricular zone (VZ). After mitosis, immature neuronal cells migrate through the intermediate zone (IZ) and the primordial plexiform layer (PPL), and become mature neurons in the cortical plate. In $\mathrm{Pol} \beta$-null mice, abnormally increased numbers of neuronal apoptotic cells are detected in E12.5-E14.5 PPL (where neurogenesis in the cortex peaks) but disappear almost completely at E18.5, following completion of neurogenesis. Pol $\beta$ expression is known to be high in brain, thymus and testis. ${ }^{9,10}$ However, in $\mathrm{Pol} \beta$-deficient embryos, ${ }^{7}$ development of tissues other than the nervous systems appears normal. These observations indicate that $\mathrm{Pol} \beta$ plays an important role in neural development. So far, some knockout mice defective in BER factors have been generated; mice deficient in FEN1, ${ }^{11}$ APE, ${ }^{12}$ $X R C C 1^{13}$ and DNA ligase I (Ligl) ${ }^{14}$ are all embryonic lethal at E3.5-E16.5. These findings clearly indicate that BER plays critical roles in development.

As in $\mathrm{Pol} \beta$-deficient mice, neuronal apoptosis has been observed in mice deficient in factors for nonhomologous endjoining (NHEJ), the major pathway that repairs DNA doublestrand breaks (DSBs) in mammalian cells and is essential for $\mathrm{V}(\mathrm{D}) \mathrm{J}$ recombination. ${ }^{15} \mathrm{NHEJ}$ relies on DNA-dependent protein kinase consisting of three subunit proteins $\mathrm{Ku} 70$, Ku80 and DNA-PKcs, together with Artemis, XRCC4 and DNA ligase IV (LiglV). ${ }^{16}$ Mice null for $\mathrm{XRCC}^{17}{ }^{\text {or } \text { LiglV }^{18}}$ undergo massive neuronal apoptosis, resulting in embryonic lethality around $\mathrm{E} 14.5 .^{17,19} \mathrm{Ku} 70^{20}$ or Ku80 ${ }^{21}$ null mice exhibit similar but less increased apoptotic cells between the VZ and PPL in E12.5-E14.5 cerebral cortex but are viable. Severe combined immunodeficiency (SCID) is known to result from a nonsense mutation that truncates the C-terminal region of DNA-PKcs protein homologous to phosphatidylinositol 3 kinase $(P I 3 K){ }^{22,23}$ The kinase activity of the DNA-PKcs protein in SCID mice is lost, but can still form a complex with 
$\mathrm{Ku}$ protein and bind to DSBs. DNA-PKcs ${ }^{\text {scid/scid }}$ mice fail to develop mature $T$ and $B$ lymphocytes owing to impaired $V(D) J$ recombination, but are viable and normal in body size. ${ }^{24,25}$ The mutant mice also exhibit slightly elevated neuronal apoptosis between the VZ and PPL at E14.5. ${ }^{26,27}$ Taken together, it is evident that apoptosis occurs in early postmitotic, immature neurons and that NHEJ plays a crucial role in neurogenesis.

Recently, a variety of interactions between factors involved in different repair pathways and cell cycle checkpoints have been reported. ${ }^{28-31}$ For example, mice defective in ataxia telangiectasia mutated (ATM) that controls cell cycle checkpoints in response to $\mathrm{DSBs}^{32}$ are viable, but $\mathrm{ATM}^{-1-} \mathrm{DNA}$ $\mathrm{PKcs}^{\text {scid/scid }}$ mice are lethal around $\mathrm{E} 11.5,{ }^{33}$ suggesting functional interactions between the two proteins. We observed a similar interaction between $\operatorname{Pol} \beta$ and ATM by generating their double-mutant mice (Sugo et al., unpublished data). Although the similarity of $\mathrm{Pol} \beta$-deficient mice and mice deficient in NHEJ proteins in neurogenesis is clear, $7,19,34,35$ there is no evidence for potential interaction between $\mathrm{Pol} \beta$ and DNA-PKcs. Hence, to explore this, we generated mice defective in both $\operatorname{Pol} \beta$ and DNA-PKcs. The resulting doublemutant mice exhibited greater developmental delay, more extensive neuronal apoptosis and earlier lethality than mice with either single defect. We also studied the involvement of p53 in the phenotype by generating triple-mutant mice deficient in $\mathrm{Pol} \beta$, DNA-PKcs, and $\mathrm{p} 53$. Neuronal apoptosis was found to be rescued by p53 deficiency, indicating dependency on the p53 pathway, but the lethality was not rescued. We suggest a genetic interaction between $\operatorname{Pol} \beta$ and DNA-PKcs in embryonic development and neurogenesis.

\section{Results}

\section{Pol $\beta^{-I-}$ DNA-PKcs ${ }^{\text {scid/scid }}$ mice are embryonic lethal earlier than Pol $\beta^{-I-}$ DNA-PKcs ${ }^{+I+}$ mice}

To assess the effect of $\operatorname{Pol} \beta$ and DNA-PKcs deficiency on embryogenesis, we first bred Pol $\beta^{+/-}$mice with SCID (DNA$\mathrm{PKcs}^{\text {scid/scid }}$ ) mice. The resulting $\mathrm{Pol} \beta^{+/-}$DNA-PKcs ${ }^{+/ s c i d}$ mice were intercrossed to obtain Pol $\beta^{-1-}$ DNA-PKcs ${ }^{\text {scid } / \text { scid }}$ mice. Among the offspring, $\mathrm{Pol} \beta^{+/+} \mathrm{DNA}-\mathrm{PKcs}{ }^{+/ \mathrm{scid}}, \mathrm{Pol} \beta^{+/-}$ DNA-PKcs ${ }^{+/+}$and Pol $\beta^{+/-}$DNA-PKcs ${ }^{+/ \text {scid }}$ mice developed normally into adulthood. Pol $\beta^{+/}$DNA-PKcs ${ }^{\text {scid/scid }}$ mice developed normally, similar to $\mathrm{Pol} \beta^{+/+}$DNA-PKcs ${ }^{\text {scid/scid }}$ mice. Pol $\beta^{-/-}$DNA-PKcs ${ }^{\text {scid/ }+}$ mice, like Pol $\beta^{-1-}$ DNA$\mathrm{PKcs}^{+1+}$ mice, died immediately after birth as described previously, ${ }^{7}$ and these mice were born at ratios close to Mendelian law (Table 1). In contrast, Pol $\beta^{-1-}$ DNA-PKcs ${ }^{\text {scid/scid }}$ double-mutant mice were represented at E11.5 but not at E12.5 (Table 1). The double-mutant embryos exhibited a profound developmental delay that was clearly evident by E9.5 (compare Figure 1a with g), and looked like E8.5
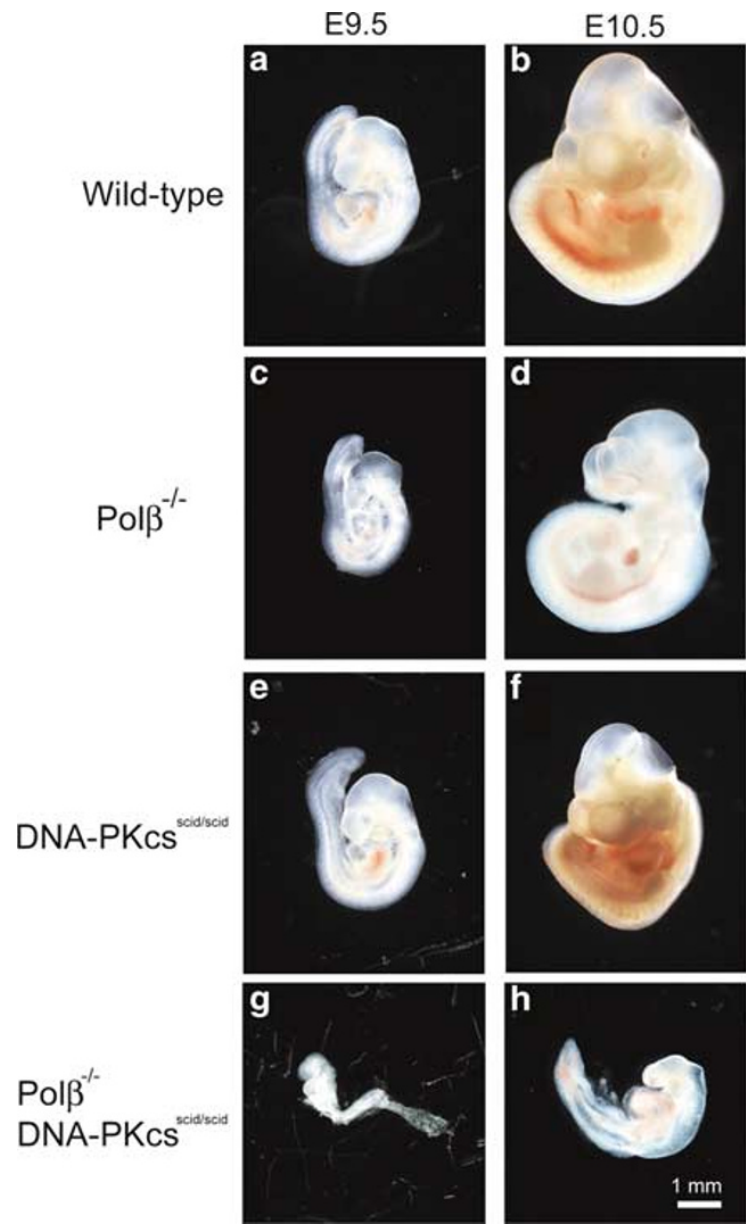

Figure 1 Lateral view of E9.5 and E10.5 embryos with different genotypes. Note that Pol $\beta^{-l-}$ DNA-PKcs ${ }^{\text {scid/scid }}$ mutant mice $(\mathbf{g}, \mathbf{h})$ display severe developmental delay

Table 1 Embryonic lethality of $\mathrm{Pol} \beta^{-/}$DNA-PKcs ${ }^{\text {scid/scid }}$ mice

\begin{tabular}{|c|c|c|c|c|c|c|c|c|c|c|}
\hline \multirow[b]{3}{*}{ Stage } & \multirow[b]{3}{*}{ Total no. of litters (no. of embryos) } & \multicolumn{9}{|c|}{ Genotype } \\
\hline & & \multicolumn{3}{|c|}{ Pol $\beta^{+/+}$} & \multicolumn{3}{|c|}{ Pol $\beta^{+\prime-}$} & \multicolumn{3}{|c|}{ Pol $\beta^{-I-}$} \\
\hline & & $+/+$ & +/scid & scid/scid & $+/+$ & +/scid & scid/scid & $+/+$ & +/scid & scid/scid \\
\hline $\begin{array}{l}\text { E9.5 } \\
\text { E10.5 } \\
\text { E11.5 } \\
\text { E12.5 } \\
\text { P0 } \\
3 \text { weeks }\end{array}$ & $\begin{array}{c}15(89) \\
22(172) \\
6(48) \\
8(44) \\
16(116) \\
20(135)\end{array}$ & $\begin{array}{r}5 \\
12 \\
5 \\
2 \\
17 \\
19\end{array}$ & $\begin{array}{r}14 \\
23 \\
0 \\
4 \\
18 \\
23\end{array}$ & $\begin{array}{r}5 \\
12 \\
9 \\
10 \\
9 \\
14\end{array}$ & $\begin{array}{r}12 \\
19 \\
6 \\
2 \\
16 \\
18\end{array}$ & $\begin{array}{r}26 \\
45 \\
7 \\
10 \\
28 \\
38\end{array}$ & $\begin{array}{r}11 \\
21 \\
7 \\
9 \\
19 \\
23\end{array}$ & $\begin{array}{r}5 \\
11 \\
6 \\
1 \\
2 \\
0\end{array}$ & $\begin{array}{r}7 \\
16 \\
3 \\
6 \\
7 \\
0\end{array}$ & $\begin{array}{r}4 \\
13 \\
5 \\
0 \\
0 \\
0\end{array}$ \\
\hline
\end{tabular}

At stages E9.5, E10.5, P0 and 3 weeks is shown the number of offspring from the intercrosses of Pol $\beta^{+/-}$DNA-PKcs ${ }^{+/ s c i d}$ mice. At stages E11.5 and E12.5, the number of offspring from the intercrosses of $\mathrm{Pol} \beta^{+/}$DNA-PKcs scid/scid mice is added to the above number at the same stage. 
wild-type embryos (data not shown). Similarly, E10.5 doublemutant embryos looked like wild-type controls at E9.0, although any specific malformations were not detected. At E11.5, double-mutant mice were resorbed in utero (data not shown). The developmental delay was not observed in either $\mathrm{Pol} \beta^{-1-}$ (Figure 1c, d) or DNA-PKcs ${ }^{\text {scid/scid }}$ (Figure 1e, f) mice, although both the single-mutant embryos were slightly smaller relative to the wild-type, as reported. ${ }^{7,36}$ These results suggest that $\mathrm{Pol} \beta$ and DNA-PKcs play an overlapping role that is important for embryogenesis.

\section{Neuronal apoptotic cells increase in E10.5 Pol $\beta^{-I-}$ DNA-PKcs ${ }^{\text {scid/scid }}$ mice}

We postulated that the lethality of double-mutant mice might be attributed to defective neuronal development. Important events in the development of mouse embryos at E9.5 are neurulation and migration of neural crest cells. ${ }^{37}$ At this stage, wild-type, Pol $\beta^{-/-}$DNA-PKcs ${ }^{+/+}$and $\mathrm{Pol} \beta^{+/+}$DNA$\mathrm{PKcs}^{\text {scid/scid }}$ mice have completed neurulation (Figure $2 a, c, e)$. However, in double-mutant mice it was delayed until E10.5 (compare Figure 2a, b with $\mathrm{g}, \mathrm{h}$ ). In previous studies, E12.5-E16.5 Pol $\beta^{-/-}$DNA-PKcs ${ }^{+/+}$mice exhibited extensive neuronal apoptosis, whereas E14.5 $\mathrm{Pol} \beta^{+/+} \mathrm{DNA}$ PKcs ${ }^{\text {scid/scid }}$ mice did mild apoptosis. ${ }^{7,26}$ To examine whether similar apoptosis occurred in mice bred in this study, we performed immunohistochemical analyses on sections of the nervous system. We used anti-cleaved caspase-3 antibody to detect apoptosis and antineuron-specific type-III $\beta$-tubulin antibody to detect neuronal differentiation. In wild-type, $\mathrm{Pol} \beta^{-/-}$DNA-PKcs ${ }^{+1+}$, and Pol $\beta^{+/+}$DNA-PKcs ${ }^{\text {scid/scid }}$ mice at E9.5-E10.5, apoptotic cells stained positive with anticleaved caspase-3 antibody were detected (Figure $3 a-1$, green); these cells were also positive for $\beta$-tubulin staining and were detected in neural crest cells developing into trigeminal ganglions (Figure 3a-I, red). Similarly, in Pol $\beta^{-1-}$ DNAPKcs ${ }^{\text {scid/scid }}$ mice at E9.5, a few neural crest cells were detected at the junction between the roof plate of neural tube and surface ectoderm (Figure $3 \mathrm{~m}$, inset); these cells migrated to neural crest tissues. However, at this stage, neuronal apoptotic cells were scarcely observed (Figure $3 m, n$ ). Strikingly, in E10.5 double-mutant mice, neuronal apoptotic cells markedly increased compared with either $\mathrm{Pol} \beta^{-I-}$ DNA$\mathrm{PKcs}^{+1+}$ or Pol $\beta^{+1+}$ DNA-PKcs ${ }^{\text {scid/scid }}$ mice (Figure 3h, l, p). We counted cells stained with both cleaved caspase- 3 and type-III $\beta$-tubulin antibodies in E10.5 trigeminal ganglions and found that the number of neuronal apoptotic cells in the double mutant mice was 2.5 -fold greater than the sum of those observed in both single-mutant mice. In addition, these apoptotic cells obviously increased during E9.5-E10.5. In Pol $\beta$-deficient, ${ }^{7} \mathrm{SCID}^{19,26}$ or NHEJ-deficient mice, ${ }^{17,19,38,39}$ neuronal apoptosis has been observed in the CNS of E12.5E16.5 mice. In this study, however, we found that in $\mathrm{Pol} \beta^{-1-}$ DNA-PKcs ${ }^{+/+}$and Pol $\beta^{+/+}$DNA-PKcs ${ }^{\text {scid/scid }}$ mice, a fraction of neuronal cells in the PNS undergoes apoptosis at earlier stages. We also found that more extensive apoptosis of neuronal cells occurs in the PNS of Pol $\beta^{-/-}$DNA-PKcs ${ }^{\text {scid/scid }}$ mice, indicating a synergistic effect of $\operatorname{Pol} \beta$ and DNA-PKcs mutations on neuronal apoptosis.

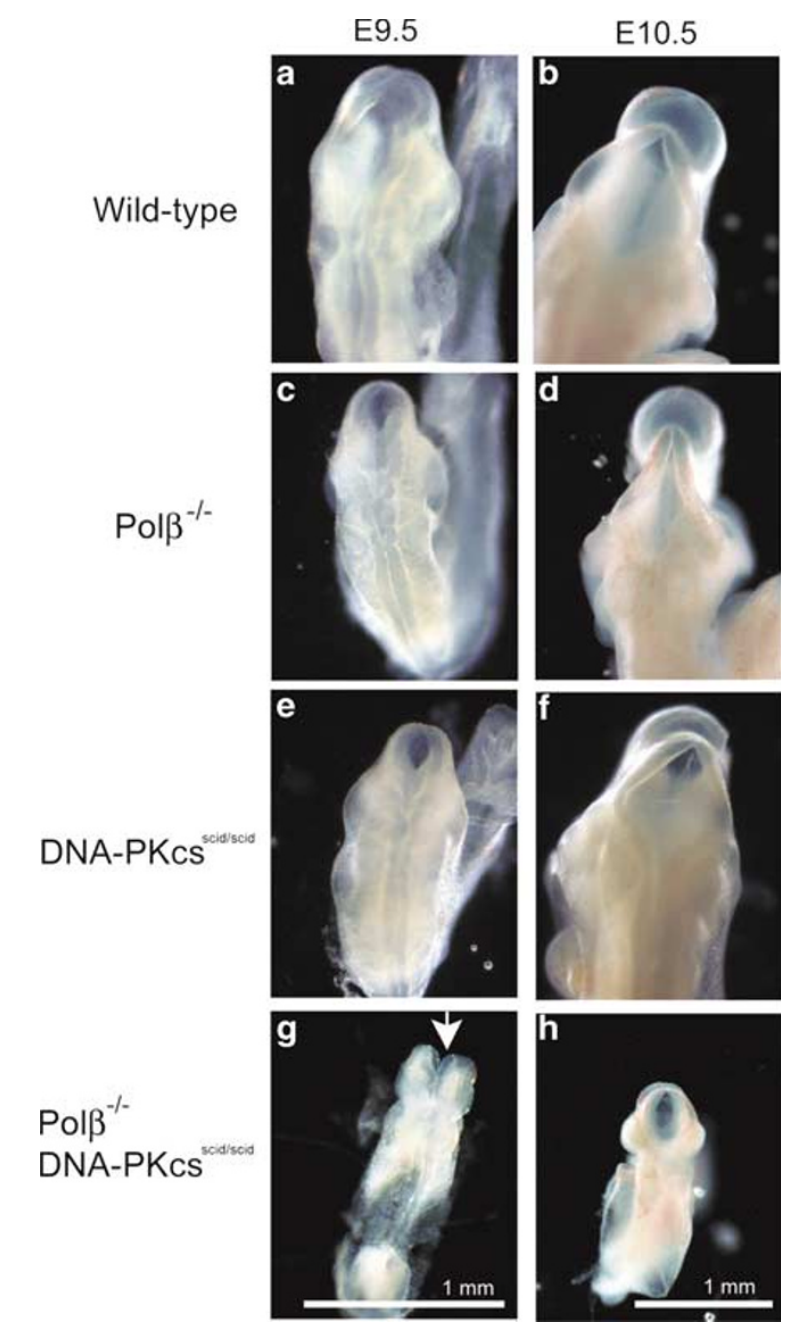

Figure 2 Dorsal view of E9.5 and E10.5 embryos with different genotypes during neurulation. Pol $\beta^{-1}$ DNA-PKcs scid/scid mice $(\mathbf{g}, \mathbf{h})$ display retardation of neurulation. The arrow in $\mathbf{g}$ represents disclosure of neural tube in E9.5 $\mathrm{Pol} \beta^{-l-}$ DNA-PKcs ${ }^{\text {scid/scid }}$ mice

\section{p53 deficiency rescues neural apoptosis but not lethality in Pol $\beta^{-I-}$ DNA-PKcs ${ }^{\text {scid/scid }}$ mice}

We observed that apoptosis associated with $\operatorname{Pol} \beta$ deficiency is mediated by the p53-dependent apoptosis pathway in the nervous system ${ }^{40}$ In SCID mice, there is no report on whether p53 deficiency rescues apoptosis in the nervous system. It is controversial whether DNA-PKcs is an upstream mediator of the p53 response to DNA damage. ${ }^{41}$ To clarify whether neuronal apoptosis in $\mathrm{Pol} \beta^{-/}$DNA-PKcs ${ }^{\text {scid/scid }}$ mice occurred via the p53-dependent pathway, we examined stabilization (and/or activation) of p53 protein in the region of trigeminal ganglion by immunohistochemical analysis. In wild-type, Pol $\beta^{-/-}$DNA-PKcs ${ }^{+/+}$or Pol $\beta^{+/+}$DNA$\mathrm{PKcs}{ }^{\text {scid/scid }}$ mice at $\mathrm{E} 9.5$ and $\mathrm{E} 10.5$, a small number of p53-stained cells were observed (Figure 4a-c, e-g). In E9.5 $\mathrm{Pol} \beta^{-1-}$ DNA-PKcs ${ }^{\text {scid/scid }}$ mice, we detected a larger number of cells (with higher p53 levels) than those in the wild type and both single-mutant mice (Figure 4d). However, as compared with the E9.5 double-mutant mice, p53-stained cells were 


\section{E9.5}
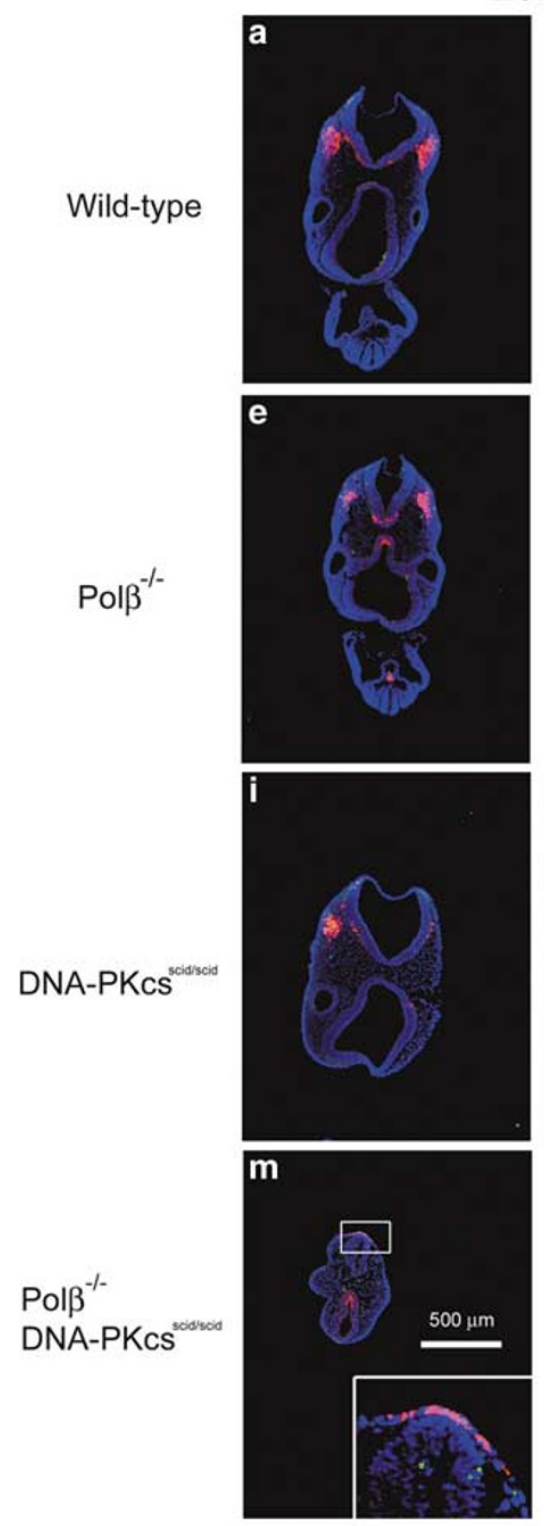
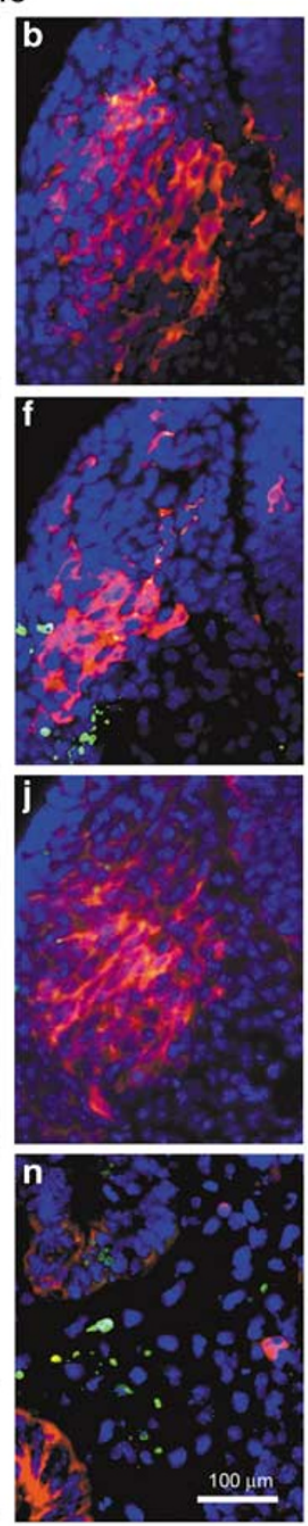

E10.5
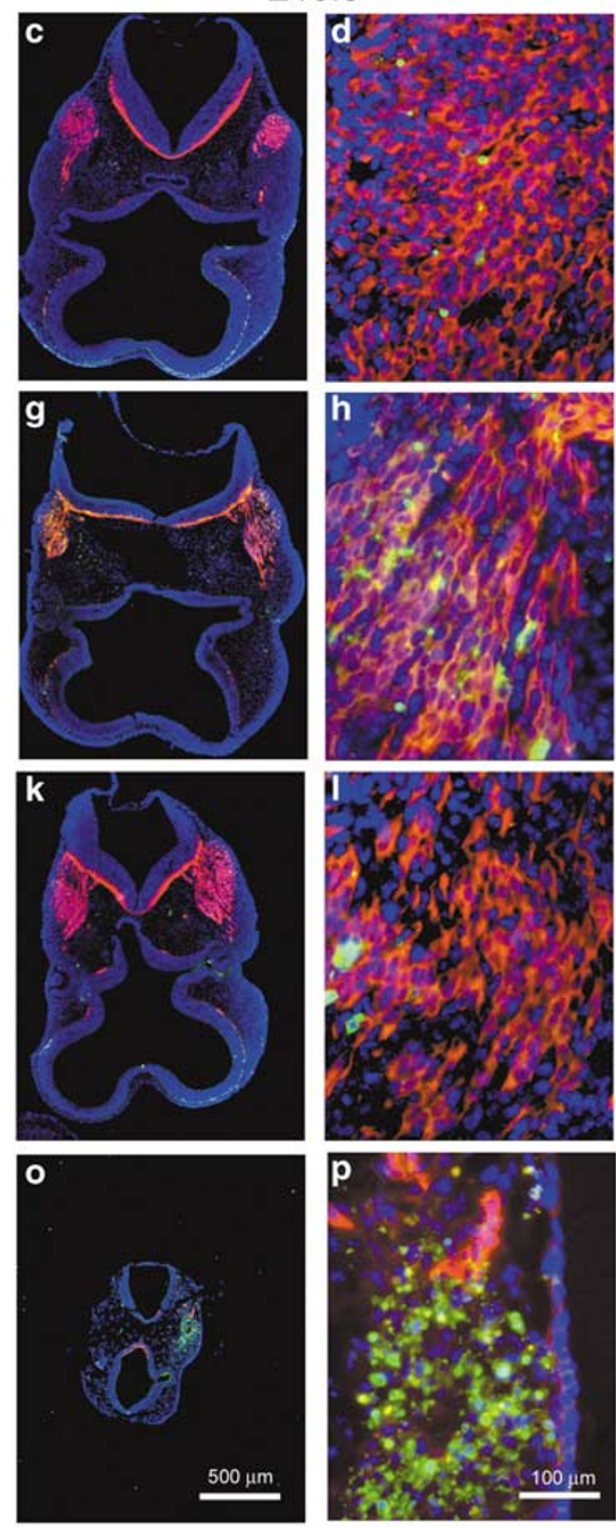

Figure 3 Immunohistochemical analysis of transverse sections in the region of trigeminal ganglions with different genotypes, using mouse anti neuron-specific type-III $\beta$-tubulin (red) antibody and rabbit anti-cleaved caspase-3 (green) antibody. Note that extensive neuronal apoptosis occurs in E10.5 Pol $\beta^{-l}$ DNA-PKcs ${ }^{\text {scid/scid }}$ mice (o-p). Magnifications are: a, c, e, g, i, k, m, o, $\times 4$; $\mathbf{b}, \mathbf{d}, \mathbf{f}, \mathbf{h}, \mathbf{j}, \mathbf{I}, \mathbf{n}, \mathbf{p}, \times 40$

obviously decreased in E10.5 mice (Figure 4h versus d). It appears that the higher levels of p53 seen in the E9.5 mice were followed by increased apoptosis in E10.5 neural crest cells (Figure $30, p)$. These results suggest that the neuronal apoptosis in $\mathrm{Pol} \beta^{-/}$DNA-PKcs ${ }^{\text {scid/scid }}$ mice depends on the p53 pathway that is activated in response to DNA damage.

Recently, we and others have shown that p53 deficiency rescues neuronal apoptosis in $\mathrm{Pol} \beta^{-1-}$, $\mathrm{LiglV}^{-1-}$ and $\mathrm{XRCC}^{-1-}$ mice $^{38,40,42}$ Furthermore, p53 deficiency is able to rescue lethality of the $\mathrm{LigIV}^{-1-}$ and $\mathrm{XRCC}^{-1-}$ mice, concomitant with the disappearance of apoptosis. These results indicate that p53 is a key factor for neuronal apoptosis responsive to DNA DSBs. In contrast, p53 deficiency cannot rescue lethality of $\mathrm{Pol} \beta$-deficient mice, ${ }^{40}$ suggesting that $\mathrm{Pol} \beta$ is a critical factor for neurogenesis. To examine whether p53 deficiency rescued apoptosis and lethality observed in $\mathrm{Pol} \beta^{-l-}$ DNA-PKcs ${ }^{\text {scid/scid }}$ double-mutant mice, we generated $\mathrm{Pol} \beta^{-/-}$DNA-PKcs ${ }^{\text {scid/scid }} \mathrm{p} 53^{-/-}$triple-mutant mice. At E9.5, triple-mutant mice showed normal morphology (Figure $5 \mathrm{a}, \mathrm{b}$; compare with wild-type views in Figures 1a and 2a). However, at E10.5 the mutant mice displayed markedly abnormal morphology characterized by defects in neural tube closure, like exencephaly (Figure 5d, e; compare with wild-type views in Figures $1 \mathrm{~b}$ and $2 \mathrm{~b}$ ). Importantly, the mutant mice (Figure $5 c, f)$ exhibited markedly reduced neuronal apoptosis 

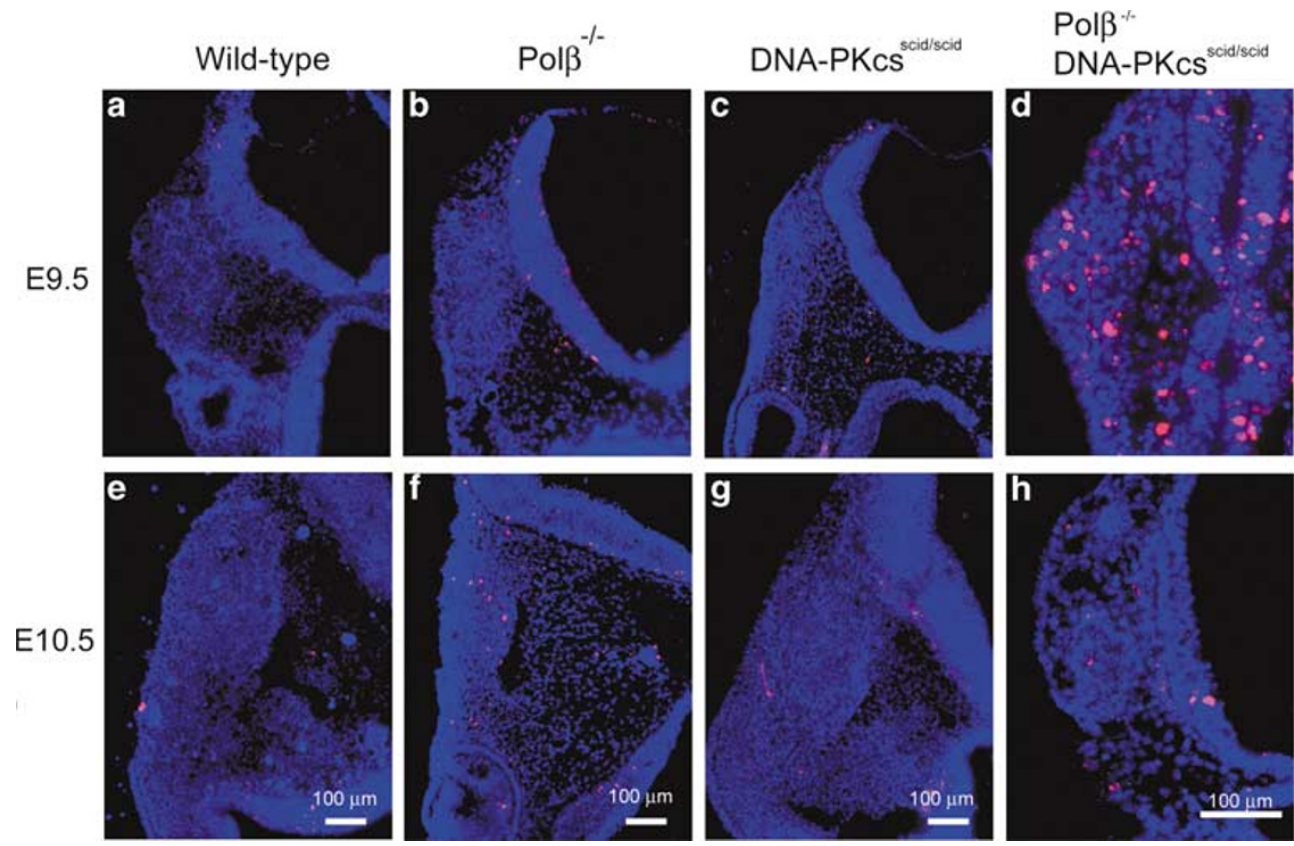

Figure 4 Immunohistochemical analysis of transverse sections in the region of trigeminal ganglions with different genotypes, using rabbit anti-p53 antibody (red). Magnifications are: a-c, e-g, $\times 10 ; \mathbf{d}, \mathbf{h}, \times 20$
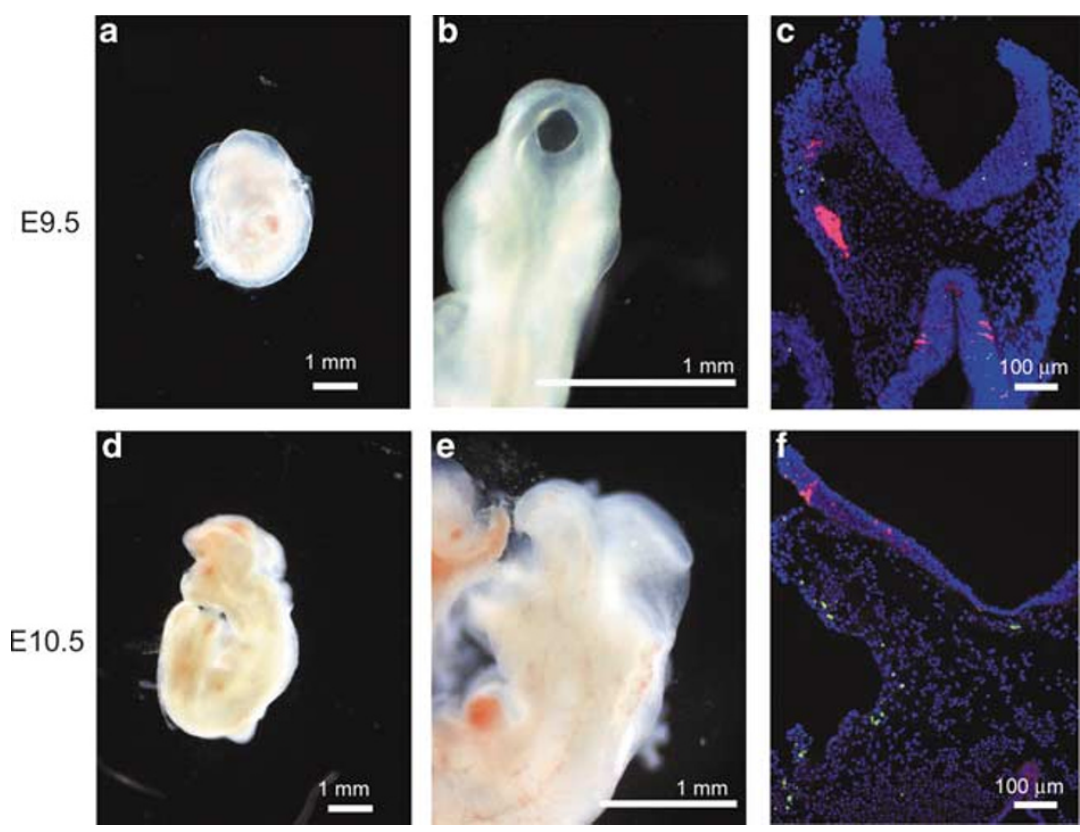

Figure 5 Lateral (a, d) and dorsal (b, e) view of Pol $\beta^{-l-}$ DNA-PKcs ${ }^{\text {scid/scid }} 553^{-l-}$ mice at E9.5 and E10.5. (c, f) Immunohistochemical analysis of transverse sections in the region of trigeminal ganglion of the triple-mutant mice, using anti neuron-specific type-III $\beta$-tubulin antibody (red) and anti-cleaved caspase-3 antibody (green). Magnifications are: $\mathbf{c}, \mathbf{f}, \times 10$

compared with Pol $\beta^{-1-}$ DNA-PKcs ${ }^{\text {scid/scid }}$ mice (Figure $3 m-p$ ), as judged by staining with anti cleaved caspase- 3 antibody. The triple-mutant embryos stopped development around E10.5 and could not be seen at E12.5. These results indicate that both $\mathrm{Pol} \beta$ and DNA-PKcs are indispensable for the process of neural tube formation via the p53-dependent pathway.

\section{Discussion}

In this study, we have generated mice doubly deficient in $\operatorname{Pol} \beta$ and DNA-PKcs. Double-mutant mice exhibited more extensive neuronal apoptosis than did wild-type, Pol $\beta^{-/-}$, or SCID mice (Figure 3). Double-mutant mice were lethal at an earlier 
embryonic stage $(\mathrm{E} 11.5)$ than $\mathrm{Pol} \beta^{-1-}$ mice (which die at birth). These results suggest a genetic interaction between $\mathrm{Pol} \beta$ and DNA-PKcs during neurogenesis and embryonic development. This might indicate a cooperation of the BER and NHEJ pathways in mammalian cells, although further studies will be required to prove the view.

$\mathrm{Pol} \beta$ is a key enzyme in the BER pathway. ${ }^{1,2} \mathrm{~A}$ modified base produced by various agents is first removed by a damage-specific DNA $N$-glycosylase to leave an AP site (this site also arises from spontaneous loss of a base). The $5^{\prime}$ side of the AP site is cleaved by APE generating a $5^{\prime}$-deoxyribose phosphate $\left(5^{\prime}\right.$-dRP) residue. Pol $\beta$ excises the $5^{\prime}$-dRP residue by its $5^{\prime}$-dRP lyase activity and fills one nucleotide in the gap, followed by ligation with Ligl or the DNA ligase III/XRCC1 complex (short-patch BER). Alternatively, the $5^{\prime}$-dRP is excised by FEN1; the resulting gap of a few nucleotides is filled in by $\mathrm{Pol} \delta / \varepsilon$ (along with or without $\mathrm{Pol} \beta$ ) followed by ligation with Ligl (long-patch BER). The Pol $\beta$ dependent, short-patch BER is dominant and proceeds so rapidly that accumulation of unrepaired BER intermediates (mostly DNA single-strand breaks (SSBs)) is prevented. However, in $\operatorname{Pol} \beta$-deficient cells, loss of $\operatorname{Pol} \beta$ would lead to the accumulation of these intermediates. ${ }^{43,44}$ As suggested previously, ${ }^{7}$ this may be the cause of the defective phenotypes including neuronal apoptosis and lethality observed in $\mathrm{Pol} \beta$-deficient mice. Mice deficient in NHEJ factors XRCC4 ${ }^{17}$ and LigIV $^{18}$ exhibit similar but more severe apoptosis phenotypes and even earlier embryonic lethality (E14.5). In contrast, mice defective in either of the DNA-PK components (DNA-PKcs, ${ }^{26} \mathrm{Ku} 70,{ }^{20} \mathrm{Ku}^{21}{ }^{21}$ ) exhibit similar but milder phenotypes with respect to neuronal apoptosis and survive during the postnatal period. In these NHEJ-deficient mice, it is thought that their phenotypes result from unrepaired DSBs caused by NHEJ deficiency. ${ }^{45}$ However, since the phenotypes of our $\mathrm{Pol} \beta$-null mice considerably differ from those of the NHEJ-deficient mice, we favor the view that unrepaired SSBs cause neuronal apoptosis and lethality associated with $\mathrm{Pol} \beta$ deficiency. ${ }^{7,40}$

Double-mutant mice deficient in $\operatorname{Pol} \beta$ and DNA-PKcs showed more severe phenotypes than $\mathrm{Pol} \beta^{-1-}$ mice as well as DNA-PKcs ${ }^{\text {scid/scid }}$ mice (Figures $\left.1-4\right)$. What is the reason for this difference? In the absence of $\mathrm{Pol} \beta$, the majority of BER intermediates mentioned above might be repaired slowly by long-patch BER or other mechanisms. However, it is possible that at least some intermediates may be changed to DSBs by collision with DNA replication forks progressing during Sphase. ${ }^{46,47}$ Furthermore, AP sites on the genome may act as poison in the presence of DNA topoisomerase II, remain unligated and change into DSBs during replication or transcription. ${ }^{48}$ In wild-type mice, these DSBs could be repaired by either NHEJ or homologous recombination (HR). In mice deficient in DNA-PKcs, the NHEJ pathway is abolished, so that the remaining HR pathway would be employed to repair these lesions but unable to repair all of

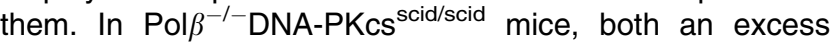
amount of unrepaired SSBs and a small, but significant, amount of unrepaired DSBs would accumulate within cells, interfere synergistically with their genomic integrity and, thus, the double-mutant mice would reveal even more severe phenotypes than either single mutant. This may be the cause of serious defects observed in embryogenesis and neurogenesis of the double-mutant mice.

Pol $\beta^{-1-}$ DNA-PKcs ${ }^{\text {scid/scid }}$ p53 $3^{-1-}$ mice showed that p53 deficiency rescues neuronal apoptosis but not embryonic lethality associated with a double deficiency of $\mathrm{Pol} \beta$ and DNAPKcs (Figure 5d, e). These results indicate that the apoptosis is mediated by the p53-dependent pathway. We have recently shown that $\mathrm{Pol} \beta^{-/-} \mathrm{p} 53^{-1-}$ mice do not exhibit neuronal apoptosis but die shortly after birth, and display cytoarchitectural abnormalities in the CNS. ${ }^{40}$ These results indicate that $\mathrm{Pol} \beta$ is critical for embryonic development, especially for neuronal development. In contrast, p53 deficiency effectively rescues embryonic lethality of both LigIV- and XRCC4deficient mice, and these mice, like DNA-PKcs ${ }^{\text {scid/scid }}{\mathrm{p} 53^{-1-}}^{-}$ mice, ${ }^{49}$ survive even in the postnatal stage but develop lymphomas at shorter latency than $\mathrm{p} 53^{-1-}$ mice..$^{38,42}$ In these double-mutant mice, deficiency in an NHEJ factor and p53 may cause genomic instability and increase chromosomal rearrangements such as deletions and translocation, leading to tumorigenesis during lymphocyte development. ${ }^{50,51}$ These results suggest that NHEJ may not be indispensable for the development of mouse embryos but instead, greatly increase the risk of tumors. It should be noted that all E10.5 $\mathrm{Pol} \beta^{-1-}$ DNA-PKcs ${ }^{\text {scid/scid }} \mathrm{p53}{ }^{-1-}$ mice exhibit defects in neural tube closure, like exencephaly (Figure 5). Such defects have

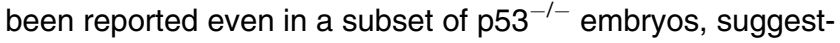
ing a crucial role of $p 53$ protein in the process of neural tube closure. ${ }^{52,53}$ Similarly, mice deficient in Pax-3, a transcription factor that is expressed in the neural tube and neural crest, ${ }^{54}$ exhibit similar neural tube defects with apoptosis and die at midgestation; importantly, this deficiency increases p53 protein levels in the embryos. Since p53 deficiency rescues the above defect in Pax-3-deficient embryos, it is suggested that Pax-3 regulates neurulation by inhibiting p53-dependent apoptosis. In addition, a considerable fraction of mice deficient in both p53 and XPC, a nucleotide excision repair protein, shows a spectrum of neural tube defects including excencephaly. ${ }^{55}$ These results suggest that the p53 level in developing neural tissues is controlled very precisely and that this allows for the normal process of neural tube closure. It is possible that both $\mathrm{Pol} \beta$ and DNA-PKcs deficiencies lead to elevated p53 levels and disrupt a balance between cell cycle arrest/DNA repair and apoptosis, causing apoptosis in specific neural cell types. Thus, even if p53 deficiency

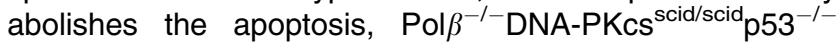
mice may suffer severe, unregulated growth of neural cells. In other words, $\operatorname{Pol} \beta$ and DNA-PKcs, coupled with p53, are likely to play an important role in the process of neurulation. Further studies will be necessary to elucidate the mechanism of developmental abnormalities caused by deficiency in DNA repair factors.

\section{Materials and Methods}

\section{Animals}

Generation and characterization of $\mathrm{Pol} \beta^{-1-}$ mice have been described. 7,40 Male Fox Chase C.B-17/ICR-ScidJcl (SCID) mice were purchased from CLEA Japan (Tokyo, Japan). p53 ${ }^{+/-}$mice (C57BL/6J-Trp53 tmITyj) were purchased from The Jackson Laboratory (West Grove, PA, USA). 
Genotypings of Pol $\beta$, DNA-PKcs, and p53 were performed by PCR analysis as previously described. ${ }^{7,22}$ All mice were maintained in a pathogen-free environment.

\section{Generation of Pol $\beta^{-I-}$ DNA-PKcs ${ }^{\text {scid/scid }}$ and Pol $\beta^{-I-}$ DNA-PKcs ${ }^{\text {scid/scid }}$ p53 ${ }^{-l-}$ mice}

$\mathrm{Pol} \beta^{+1-}$ mice were mated to SCID mice and the resulting $\mathrm{Pol} \beta^{+/-}$DNA$\mathrm{PKcs}{ }^{\text {scid } /+}$ mice were intercrossed to generate $\mathrm{Pol} \beta^{-1-}$ DNA-PKcs ${ }^{\text {scid/scid }}$ mice. Also Pol $\beta^{+/-}$DNA-PKcs scid/scid mice were mated to $\mathrm{p} 53^{+/-}$mice to generate $\mathrm{Pol} \beta^{+/-}$DNA-PKcs ${ }^{\mathrm{scid} /}+\mathrm{p} 53^{+/-}$mice, which were then intercrossed to generate Pol $\beta^{-1-}$ DNA-PKcs ${ }^{\text {scid/scid }} \mathrm{p} 53^{-1-}$ mice.

\section{Histological analyses}

Whole embryos were fixed, embedded, and sectioned $(10 \mu \mathrm{m})$, as described. ${ }^{7,40}$ The sections were immunostained as described, ${ }^{7,40}$ except for p53 staining where TSA Biotin System (PerkinElmer Life Sciences) as anti-p53 antibody was used.

\section{Acknowledgements}

We thank A Oonuma for animal care. We also thank Dr. N Adachi for critical reading of the manuscript. NS was a recipient of Research Fellowship of the Japan Society for the Promotion of Science for Young Scientists. This work was supported in part by Grant-in-Aid for Scientific Research (C) from The Ministry of Education, Culture, Sports, Science, and Technology of Japan.

\section{References}

1. Wilson SH (1998) Mammalian base excision repair and DNA polymerase $\beta$. Mutat. Res. 407: 203-215

2. Matsumoto $Y$ and Kim K (1995) Excision of deoxyribose phosphate residues by DNA polymerase $\beta$ during DNA repair. Science 269: 699-702

3. Sobol RW, Horton JK, Kuhn R, Gu H, Singhal RK, Prasad R, Rajewsky K and Wilson SH (1996) Requirement of mammalian DNA polymerase $\beta$ in baseexcision repair. Nature 379: 183-186

4. Fortini P, Pascucci B, Belisario F and Dogliotti E (2000) DNA polymerase $\beta$ is required for efficient DNA strand break repair induced by methyl methanesulfonate but not by hydrogen peroxide. Nucleic Acids Res. 28 : 3040-3046

5. Esposito G, Texido G, Betz UA, Gu H, Muller W, Klein U and Rajewsky $K$ (2000) Mice reconstituted with DNA polymerase $\beta$-deficient fetal liver cells are able to mount a T cell-dependent immune response and mutate their Ig genes normally. Proc. Natl. Acad. Sci. USA 97: 1166-1171

6. Gu H, Marth JD, Orban PC, Mossmann H and Rajewsky K (1994) Deletion of a DNA polymerase $\beta$ gene segment in T cells using cell type-specific gene targeting. Science 265: 103-106

7. Sugo N, Aratani Y, Nagashima Y, Kubota $Y$ and Koyama $H(2000)$ Neonatal lethality with abnormal neurogenesis in mice deficient in DNA polymerase $\beta$. EMBO J. 19: 1397-1404

8. Lopez-Bendito $G$ and Molnar Z (2003) Thalamocortical development: how are we going to get there? Nat. Rev. Neurosci. 4: 276-289

9. Hirose F, Hotta Y, Yamaguchi M and Matsukage A (1989) Difference in the expression level of DNA polymerase $\beta$ among mouse tissues: high expression in the pachytene spermatocyte. Exp. Cell Res. 181: 169-180

10. Nowak R, Woszczynski M and Siedlecki JA (1990) Changes in the DNA polymerase $\beta$ gene expression during development of lung, brain, and testis suggest an involvement of the enzyme in DNA recombination. Exp. Cell Res. 191: $51-56$
11. Kucherlapati M, Yang K, Kuraguchi M, Zhao J, Lia M, Heyer J, Kane MF, Fan K Russell R, Brown AM, Kneitz B, Edelmann W, Kolodner RD, Lipkin M and Kucherlapati R (2002) Haploinsufficiency of Flap endonuclease (Fen1) leads to rapid tumor progression. Proc. Natl. Acad. Sci. USA 99: 9924-9929

12. Xanthoudakis S, Smeyne RJ, Wallace JD and Curran T (1996) The redox/DNA repair protein, Ref-1, is essential for early embryonic development in mice. Proc. Natl. Acad. Sci. USA 93: 8919-8923

13. Tebbs RS, Flannery ML, Meneses JJ, Hartmann A, Tucker JD, Thompson LH, Cleaver JE and Pedersen RA (1999) Requirement for the Xrcc1 DNA base excision repair gene during early mouse development. Dev. Biol. 208: 513-529

14. Bentley D, Selfridge J, Millar JK, Samuel K, Hole N, Ansell JD and Melton DW (1996) DNA ligase I is required for fetal liver erythropoiesis but is not essential for mammalian cell viability. Nat. Genet. 13: 489-491

15. Critchlow SE and Jackson SP (1998) DNA end-joining: from yeast to man. Trends Biochem. Sci. 23: 394-398

16. Lieber MR, Ma Y, Pannicke U and Schwarz K (2003) Mechanism and regulation of human non-homologous DNA end-joining. Nat. Rev. Mol. Cell Biol. 4: 712-720

17. Gao $Y$, Sun $Y$, Frank KM, Dikkes $P$, Fujiwara $Y$, Seidl KJ, Sekiguchi JM, Rathbun GA, Swat W, Wang J, Bronson RT, Malynn BA, Bryans M, Zhu C, Chaudhuri J, Davidson L, Ferrini R, Stamato T, Orkin SH, Greenberg ME and Alt FW (1998) A critical role for DNA end-joining proteins in both lymphogenesis and neurogenesis. Cell 95: 891-902

18. Barnes DE, Stamp G, Rosewell I, Denzel A and Lindahl T (1998) Targeted disruption of the gene encoding DNA ligase IV leads to lethality in embryonic mice. Curr. Biol. 8: 1395-1398

19. Gu Y, Sekiguchi J, Gao Y, Dikkes P, Frank K, Ferguson D, Hasty P, Chun J and Alt FW (2000) Defective embryonic neurogenesis in Ku-deficient but not DNAdependent protein kinase catalytic subunit-deficient mice. Proc. Natl. Acad. Sci. USA 97: 2668-2673

20. Gu Y, Jin S, Gao Y, Weaver DT and Alt FW (1997) Ku70-deficient embryonic stem cells have increased ionizing radiosensitivity, defective DNA end-binding activity, and inability to support V(D)J recombination. Proc. Natl. Acad. Sci. USA 94: 8076-8081

21. Nussenzweig A, Chen C, da Costa Soares V, Sanchez M, Sokol K, Nussenzweig MC and Li GC (1996) Requirement for Ku80 in growth and immunoglobulin $V(D) J$ recombination. Nature 382: 551-555

22. Blunt T, Gell D, Fox M, Taccioli GE, Lehmann AR, Jackson SP and Jeggo PA (1996) Identification of a nonsense mutation in the carboxyl-terminal region of DNA-dependent protein kinase catalytic subunit in the scid mouse. Proc. Natl. Acad. Sci. USA 93: 10285-10290

23. Kirchgessner CU, Patil CK, Evans JW, Cuomo CA, Fried LM, Carter T, Oettinger MA and Brown JM (1995) DNA-dependent kinase (p350) as a candidate gene for the murine SCID defect. Science 267: 1178-1183

24. Blackwell TK, Malynn BA, Pollock RR, Ferrier P, Covey LR, Fulop GM, Phillips RA, Yancopoulos GD and Alt FW (1989) Isolation of scid pre-B cells that rearrange kappa light chain genes: formation of normal signal and abnormal coding joins. EMBO J. 8: 735-742

25. Malynn BA, Blackwell TK, Fulop GM, Rathbun GA, Furley AJ, Ferrier P, Heinke LB, Phillips RA, Yancopoulos GD and Alt FW (1988) The scid defect affects the final step of the immunoglobulin VDJ recombinase mechanism. Cell 54: 453-460

26. Vemuri MC, Schiller E and Naegele JR (2001) Elevated DNA double strand breaks and apoptosis in the CNS of scid mutant mice. Cell Death Differ. 8: 245-255

27. Chechlacz M, Vemuri MC and Naegele JR (2001) Role of DNA-dependent protein kinase in neuronal survival. J. Neurochem. 78: 141-154

28. Morrison C, Smith GC, Stingl L, Jackson SP, Wagner EF and Wang ZQ (1997) Genetic interaction between PARP and DNA-PK in V(D)J recombination and tumorigenesis. Nat. Genet. 17: 479-482

29. Motycka TA, Bessho T, Post SM, Sung P and Tomkinson AE (2004) Physical and functional interaction between the XPF/ERCC1 endonuclease and hRad52. J. Biol. Chem. 279: 13634-13639

30. Plosky B, Samson L, Engelward BP, Gold B, Schlaen B, Millas T, Magnotti M, Schor J and Scicchitano DA (2002) Base excision repair and nucleotide excision repair contribute to the removal of $N$-methylpurines from active genes. DNA Repair (Amsterdam) 1: 683-696

31. Zhou BB and Elledge SJ (2000) The DNA damage response: putting checkpoints in perspective. Nature 408: 433-439 
32. Valerie K and Povirk LF (2003) Regulation and mechanisms of mammalian double-strand break repair. Oncogene 22: 5792-5812

33. Gurley KE and Kemp CJ (2001) Synthetic lethality between mutation in Atm and DNA-PK(cs) during murine embryogenesis. Curr. Biol. 11: 191-194

34. Gao Y, Chaudhuri J, Zhu C, Davidson L, Weaver DT and Alt FW (1998) A targeted DNA-PKcs-null mutation reveals DNA-PK-independent functions for $\mathrm{KU}$ in $\mathrm{V}(\mathrm{D}) \mathrm{J}$ recombination. Immunity 9: 367-376

35. Oka A, Takashima S, Abe M, Araki R and Takeshita K (2000) Expression of DNA-dependent protein kinase catalytic subunit and Ku80 in developing human brains: implication of DNA-repair in neurogenesis. Neurosci. Lett. 292: 167-170

36. Bosma GC, Custer RP and Bosma MJ (1983) A severe combined immunodeficiency mutation in the mouse. Nature 301: 527-530

37. Kaufman MH (2002) The Atlas of Mouse Development, $2^{\text {nd }}$ edn UK: Academic Press

38. Frank KM, Sharpless NE, Gao Y, Sekiguchi JM, Ferguson DO, Zhu C, Manis JP, Horner J, DePinho RA and Alt FW (2000) DNA ligase IV deficiency in mice leads to defective neurogenesis and embryonic lethality via the p53 pathway. Mol. Cell 5: 993-1002

39. Lee Y, Barnes DE, Lindahl T and McKinnon PJ (2000) Defective neurogenesis resulting from DNA ligase IV deficiency requires Atm. Genes Dev. 14: 25762580

40. Sugo N, Niimi N, Aratani Y, Takiguchi-Hayashi K and Koyama H (2004) p53 deficiency rescues neuronal apoptosis but not differentiation in DNA polymerase $\beta$-deficient mice. Mol. Cell. Biol. 24: 9470-9477

41. Yang J, Yu Y, Hamrick HE and Duerksen-Hughes PJ (2003) ATM, ATR and DNA-PK: initiators of the cellular genotoxic stress responses. Carcinogenesis 24: $1571-1580$

42. Gao Y, Ferguson DO, Xie W, Manis JP, Sekiguchi J, Frank KM, Chaudhuri J, Horner J, DePinho RA and Alt FW (2000) Interplay of p53 and DNA-repair protein XRCC4 in tumorigenesis, genomic stability and development. Nature 404: 897-900

43. Sobol RW, Prasad R, Evenski A, Baker A, Yang XP, Horton JK and Wilson SH (2000) The lyase activity of the DNA repair protein $\beta$-polymerase protects from DNA damage-induced cytotoxicity. Nature 405: 807-810

44. Sobol RW, Kartalou M, Almeida KH, Joyce DF, Engelward BP, Horton JK, Prasad R, Samson LD and Wilson SH (2003) Base excision repair intermediates induce p53-independent cytotoxic and genotoxic responses. J. Biol. Chem. 278: 39951-39959

45. Gilmore EC, Nowakowski RS, Caviness Jr VS and Herrup K (2000) Cell birth, cell death, cell diversity and DNA breaks: how do they all fit together? Trends Neurosci. 23: 100-105

46. Vilenchik MM and Knudson AG (2003) Endogenous DNA double-strand breaks: production, fidelity of repair, and induction of cancer. Proc. Natl. Acad. Sci. USA 100: 12871-12876

47. Kuzminov A (2001) Single-strand interruptions in replicating chromosomes cause double-strand breaks. Proc. Natl. Acad. Sci. USA 98: 8241-8246

48. Bromberg KD, Burgin $A B$ and Osheroff $N$ (2003) Quinolone action against human topoisomerase $\mathrm{Il} \alpha$ : stimulation of enzyme-mediated double-stranded DNA cleavage. Biochemistry 42: 3393-3398

49. Gurley KE, Vo K and Kemp CJ (1998) DNA double-strand breaks, p53, and apoptosis during lymphomagenesis in scid/scid mice. Cancer Res. 58: 31113115

50. Difilippantonio MJ, Petersen S, Chen HT, Johnson R, Jasin M, Kanaar R, Ried $T$ and Nussenzweig A (2002) Evidence for replicative repair of DNA doublestrand breaks leading to oncogenic translocation and gene amplification. J. Exp. Med. 196: 469-480

51. Akyuz N, Boehden GS, Susse S, Rimek A, Preuss U, Scheidtmann KH and Wiesmuller $L$ (2002) DNA substrate dependence of p53-mediated regulation of double-strand break repair. Mol. Cell. Biol. 22: 6306-6317

52. Sah VP, Attardi LD, Mulligan GJ, Williams BO, Bronson RT and Jacks T (1995) A subset of p53-deficient embryos exhibit exencephaly. Nat. Genet. 10: $175-180$

53. Armstrong JF, Kaufman MH, Harrison DJ and Clarke AR (1995) Highfrequency developmental abnormalities in p53-deficient mice. Curr. Biol. 5: 931-936

54. Pani L, Horal M and Loeken MR (2002) Rescue of neural tube defects in Pax-3deficient embryos by p53 loss of function: implications for Pax-3- dependent development and tumorigenesis. Genes Dev. 16: 676-680

55. Cheo DL, Meira LB, Hammer RE, Burns DK, Doughty AT and Friedberg EC (1996) Synergistic interactions between XPC and p53 mutations in doublemutant mice: neural tube abnormalities and accelerated UV radiation-induced skin cancer. Curr. Biol. 6: 1691-1694 